\section{Are Anticoagulants required after High Tibial Osteotomy to Prevent Venous Thromboem- bolism Events? A Systematic Review}

Frank R Noyes ${ }^{1}$, Sue D Barber-Westin ${ }^{1 *}$, and Martin S Levy ${ }^{2}$

${ }^{1}$ Cincinnati Sports medicine and Orthopaedic Center, Noyes Knee Institute, The Jewish Hospital-Mercy Health, Cincinnati, Ohio, USA

${ }^{2}$ Operations and Business Analytics and Information Systems, Lindner College of Business, University of Cincinnati, Cincinnati, Ohio, USA

\begin{abstract}
\section{Introduction}

High Tibial Osteotomy (HTO) is an operation that, although well-established, may be associated with complications including venous thromboembolism events. There is no consensus regarding postoperative thromboprophylaxis, including the routine use of anticoagulants. This review investigated two questions: (1) what are the incidence rates of venous thromboembolism events after HTO, and (2) what is the routine use of anticoagulants required in standard-risk patients?

Methods

We conducted a systematic review of PubMed and Cochrane databases from 1999 through 2014 using search terms high tibial osteotomy, HTO complications, HTO DVT, opening wedge osteotomy and closing wedge osteotomy. One-hundred and seven studies were included (opening-wedge osteotomy 3923 knees and closing-wedge osteotomy 3172 knees).

Results

The overall incidence rates of deep venous thrombosis and pulmonary embolism were $1.24 \%$ and $0.11 \%$, respectively. Anticoagulants were used in 1,110 patients and aspirin was used in 312 patients. The relative risk of DVT was higher in patients that used anticoagulants compared with patients that did not use any form of chemoprophylaxis $(1.99 \%$ and $1.11 \%$, respectively; $P=0.02)$. The risk of DVT was higher in closing-wedge osteotomies compared with opening-wedge osteotomies regardless of the use of anticoagulants.

\section{Conclusion}

The incidence of venous thromboembolism events was very low after HTO, regardless of the use of chemoprophylaxis. Therefore,
\end{abstract}

*Corresponding author: Sue D Barber-Westin, Cincinnati Sports Medicine and Orthopaedic Center, Noyes Knee Institute, The Jewish Hospital-Mercy Health, Cincinnati, Ohio, USA, Tel: +1 5133479999; E-mail: sbwestin@csmref.org

Citation: Noyes FR, Barber-Westin SD, Levy MS (2017) Are Anticoagulants required after High Tibial Osteotomy to Prevent Venous Thromboembolism Events? A Systematic Review. J Orthop Res Physiother 3: 030.

Received: January 28, 2017; Accepted: May 29, 2017; Published: June 12, 2017 the necessity for anticoagulation after HTO in patients who do not have significant risk factors is questioned considering the side effects that may occur with these agents.

\section{Introduction}

High Tibial Osteotomy (HTO) is an operation that, although well-established, may be associated with complications [1,2] including Deep Venous Thrombosis (DVT) that may occur in up to $5 \%$ of patients [2-5]. Several authors have recommended postoperative thromboprophylaxis programs for HTO that are similar to those used after Total Knee Arthroplasty (TKA) [2-5]; however, the appropriate program is not supported by clinical studies. Whether anticoagulants should be routinely used postoperatively in patients who do not have significant risk factors for DVT is unknown. In addition, the role of aspirin, mechanical compressive devices, early mobilization and exercises such as immediate range of knee motion in decreasing the incidence of venous thromboembolism events after HTO has not been addressed.

This study was designed to address two primary questions: (1) What are the incidence rates of DVT and Pulmonary Embolism (PE) after modern HTO and (2) is the routine use of anticoagulants required in patients who do not have significant risk factors for venous thromboembolism events? Significant risk factors include personal or family history of DVT, obesity, use of oral contraceptives, and well-recognized hereditary disorders such as protein C deficiency, protein S deficiency and antithrombin III deficiency. In addition, secondary questions were developed to address comparisons between and within opening- and closing-wedge osteotomy studies and postoperative rehabilitation factors (Table 1).

\begin{tabular}{|c|c|}
\hline Primary: All studies & What is the incidence of DVT and PE after modern \\
HTO?
\end{tabular}


PRISM guidelines were followed in conducting this study [6]. An online search was performed using Medline and Cochrane databases from April 1999 through April 2014. Search terms included High Tibial Osteotomy, HTO complications, HTO DVT, opening wedge osteotomy and closing wedge osteotomy. The resulting titles and abstracts were screened to determine eligibility. The full text was retrieved and reviewed if the abstract suggested that this might be a study in our topic of interest. The references of each article that met the inclusionary criteria were searched to find any other articles not otherwise obtained.

The online search initially identified 382 original research articles. A total of 275 were excluded for the reasons shown in table 2. This left 107 research investigations (Appendix 1) that met the following inclusionary criteria: (1) English language, (2) opening-wedge or closing-wedge osteotomy clinical studies of all evidence levels and (3) postoperative incidence rates of DVT and/or PE provided.

\begin{tabular}{|c|c|}
\hline Exclusionary Criteria & Number of Studies \\
\hline Off topic & 87 \\
\hline Study related to biomechanics or anatomy only & 39 \\
\hline $\begin{array}{l}\text { Review article, no discussion of thromboprophylaxis } \\
\text { protocol }\end{array}$ & 48 \\
\hline \multicolumn{2}{|l|}{ HTO clinical study: } \\
\hline $\begin{array}{l}\text { Thromboprophylaxis protocol or incidence rates of DVT/ } \\
\qquad \text { PE not reported }\end{array}$ & 36 \\
\hline $\begin{array}{c}\text { Rate of DVT/PE not reported according to type of } \\
\text { osteotomy }\end{array}$ & 5 \\
\hline Prophylaxis program used, but not described & 8 \\
\hline Study on radiographic or computer navigation data only & 30 \\
\hline HTO technique paper & 17 \\
\hline Other & 5 \\
\hline
\end{tabular}

Table 2: Exclusionary criteria of 382 original research studies identified.

Abbreviations: DVT-Deep Venous Thrombosis; HTO-High Tibial Osteotomy; PE-Pulmonary Embolism

Exclusionary criteria were as follows: (1) articles that were off topic (2) articles that failed to achieve the inclusionary criteria listed previously (3) studies that did not provide any information regarding thromboprophylaxis or incidence rates of DVT and/or PE (4) studies that only provided radiologic or intra operative measurement data (5) investigations on other types of osteotomy such as dome and hemicallotasis and (6) other types of articles such as case reports, abstracts and technical notes.

Each study that met the inclusion criteria was abstracted for information regarding the following: (1) the level of evidence as determined by the journal of publication [7,8], (2) number of patients and knees (3) number of males and females (4) age at osteotomy (5) months or years of follow-up (6) type of osteotomy (opening-wedge or closing-wedge) (7) number of DVT (either calf, distal thigh, or site not given) and PE events (8) outcome of treatment for venous thromboembolism events (9) any recommended thromboprophylaxis protocol (10) time when partial weight-bearing was allowed postoperatively and (11) time when range of knee motion exercises began postoperatively. The findings were reviewed by two of the authors (FRN and SBW) and agreement reached regarding the data extracted.

The thromboprophylaxis protocols were divided into three subgroups according to the usage of chemoprophylaxis agents: none, anticoagulants (heparin, warfarin, or low-molecular-weight-heparin) and anti platelets (aspirin). One of us (MSL) calculated Odds Ratios (OR), 95\% Confidence Intervals (CI) and $P$ values to compare the magnitude of risk for the development of DVT between closing-wedge and opening-wedge osteotomies with and without chemoprophylaxis. In addition, the effects of anticoagulants versus aspirin in reducing the risk were determined between and within the two types of osteotomies. Because there were patients that underwent staged bilateral HTOs, the percent rates were calculated according to the number of knees and not the number of patients.

\section{Results}

The level of evidence was I in $13 \%$ of the studies, II in $9 \%$, III in $12 \%$, and IV in $66 \%$. The overall incidence rates of DVD and PE after HTO were $1.24 \%$ and $0.11 \%$, respectively (Table 3 ).

Anticoagulants were used in 1,110 patients and aspirin was used in 312 patients (Table 4). The relative risk of DVT was higher in patients that used anticoagulants compared with patients that did not use any form of chemoprophylaxis ( $1.99 \%$ and $1.11 \%$, respectively; $\mathrm{P}=0.02)$. There was no significant difference in the incidence rates of DVT between patients who used aspirin and patients who used no chemoprophylaxis agents, or between patients who used anticoagulants and those who used aspirin.

The risk of DVT was higher in patients who underwent closing-wedge osteotomy compared with those who underwent opening-wedge osteotomy when no chemoprophylaxis was used $(\mathrm{P}<0.0001$; Table 5). When anticoagulants were used postoperatively, the risk of DVT was also higher in closing-wedge osteotomy studies $(\mathrm{P}=0.03)$. However, when aspirin was used postoperatively, there was no significant difference in the risk of DVT between closing-wedge and opening-wedge osteotomy studies.

The use of anticoagulants or aspirin did not significantly reduce the incidence of DVT within closing-wedge or opening-wedge studies (Table 6).

It was not possible to analyze the potential effect of the postoperative rehabilitation program with regard to the use of mechanical compressive devices and the initiation of range of knee motion exercises and mobilization on the risk of DVT. Nearly one-third of the studies did not provide specific information on these factors. Although the closing-wedge osteotomy studies were generally performed in an earlier time period (2000 to 2008), it cannot be assumed that these rehabilitation factors were different than those used in the more recently published opening-wedge studies.

\section{Discussion}

There is no consensus regarding postoperative thromboprophylaxis, including the routine use of anticoagulants, after HTO. This study was designed to address two primary questions. First, what is the incidence of DVT and PE after modern HTO? Second, is the routine use of anticoagulants required in patients who do not have significant risk factors for venous thromboembolism events?

This study found that the overall incidence of PE after HTO was exceedingly low $(0.11 \%)$ regardless of the use of chemoprophylaxis. Only one fatal PE was reported in the 7095 knees that occurred 2 weeks postoperatively in a study in which warfarin had been administered, but the dosage, duration and risk factors were not provided [9]. The overall incidence of DVT was also low (1.24\%). For unknown reasons, when all osteotomy studies were combined, the patients that 
Citation: Noyes FR, Barber-Westin SD, Levy MS (2017) Are Anticoagulants required after High Tibial Osteotomy to Prevent Venous Thromboembolism Events? A Systematic Review. J Orthop Res Physiother 3: 030.

- Page 3 of 8 •

\begin{tabular}{|c|c|c|c|c|c|c|c|c|}
\hline \multirow[t]{2}{*}{ Type of Osteotomy } & \multirow{2}{*}{$\begin{array}{l}\text { Number of } \\
\text { Studies }\end{array}$} & \multirow{2}{*}{$\begin{array}{l}\text { Number of } \\
\text { Knees }\end{array}$} & \multicolumn{2}{|c|}{ Gender } & \multicolumn{2}{|c|}{ Age (Years) } & \multirow{2}{*}{$\begin{array}{l}\text { Number of } \\
\text { Knees with } \\
\text { DVT (\%) }\end{array}$} & \multirow{2}{*}{$\begin{array}{c}\text { Number of } \\
\text { Knees with } \\
\text { PE (\%) }\end{array}$} \\
\hline & & & Men & Women & Mean & Range & & \\
\hline Closing-wedge, chemoprophylaxis used & $8 \#$ & 799 & 443 & 236 & 49 & $16-77$ & $20(2.5)$ & $6(0.75)$ \\
\hline Opening-wedge, Chemoprophylaxis used & $14 \#$ & 623 & 367 & 243 & 45 & $15-67$ & $5(0.80)$ & $1(0.16)$ \\
\hline Closing-wedge, chemoprophylaxis not used & $35^{\wedge}$ & 2373 & 651 & 744 & 53 & $19-81$ & $48(2.0)$ & $1(0.04)$ \\
\hline Opening-wedge, chemoprophylaxis not used & $57^{\wedge}$ & 3300 & 1245 & 936 & 48 & $10-84$ & $15(0.45)$ & 0 \\
\hline Total & 107 & 7095 & 2706 & 2159 & 47 & $10-84$ & $88(1.24)$ & $8(0.11)$ \\
\hline
\end{tabular}

Table 3: Study demographics and incidence rates of deep venous thrombosis and pulmonary embolism.

$\wedge$ Includes 5 studies that compared opening-wedge with closing-wedge osteotomy in which venous thromboembolism event data were given for each type of osteotomy.

\#Includes 2 studies that compared opening-wedge with closing-wedge osteotomy in which venous thromboembolism event data were given for each type of osteotomy.

Abbreviations: DVT-Deep Venous Thrombosis; PE-Pulmonary Embolism

\begin{tabular}{|c|c|c|c|c|}
\hline Chemoprophylaxis (No. of Knees) & Number of Knees with DVT (\%) & Odds Ratio & $95 \% \mathrm{Cl}$ & $\mathbf{P}$ \\
\hline $\begin{array}{l}\text { Anticoagulants (1110) } \\
\text { None (5673) }\end{array}$ & $\begin{array}{l}22(1.99) \\
63(1.11)\end{array}$ & 1.8 & $1.10-2.94$ & 0.02 \\
\hline $\begin{array}{l}\text { Aspirin (312) } \\
\text { None (5673) }\end{array}$ & $\begin{array}{l}6(1.92) \\
63(1.11)\end{array}$ & 1.75 & $0.75-4.06$ & NS \\
\hline $\begin{array}{l}\text { Anticoagulants (1110) } \\
\text { Aspirin (312) }\end{array}$ & $\begin{array}{l}22(1.99) \\
6(1.92)\end{array}$ & 1.03 & $0.41-2.57$ & NS \\
\hline
\end{tabular}

Table 4: Risk of DVT according to chemoprophylaxis used postoperatively.

Abbreviations: Cl-Confidence Interval; DVT-Deep Venous Thrombosis; NS-Not Significant

\begin{tabular}{|c|c|c|c|c|}
\hline Chemoprophylaxis & $\begin{array}{c}\text { Type osteotomy (No. of } \\
\text { Knees) }\end{array}$ & $\begin{array}{c}\text { Number of Knees with } \\
\text { DVT (\%) }\end{array}$ & Odds Ratio & $\mathbf{P}$ \\
\hline \multirow{2}{*}{ None } & $\begin{array}{c}\text { Closing-wedge (2373) } \\
\text { Opening-wedge (3300) }\end{array}$ & $\begin{array}{c}48(2.02) \\
15(0.45)\end{array}$ & 4.52 & $2.53-8.09$ \\
\hline Anticoagulants & $\begin{array}{c}\text { Closing-wedge (737) } \\
\text { Opening-wedge (373) }\end{array}$ & $\begin{array}{c}20(2.71) \\
2(0.54)\end{array}$ & 5.17 & $1.20-22.26$ \\
\hline Aspirin & $\begin{array}{c}\text { Closing-wedge (62) } \\
\text { Opening-wedge (250) }\end{array}$ & $\begin{array}{c}3(4.84) \\
3(1.20)\end{array}$ & 4.19 & 0.03 \\
\hline
\end{tabular}

Table 5 : Comparison DVT incidence rates: opening- versus closing-wedge osteotomies

Abbreviations: Cl-Confidence Interval; DVT-Deep Venous Thrombosis

\begin{tabular}{|c|c|c|c|c|}
\hline Type of Osteotomy & $\begin{array}{c}\text { Chemoprophylaxis (No. of } \\
\text { Knees) }\end{array}$ & $\begin{array}{c}\text { Number of Knees with DVT } \\
(\%)\end{array}$ & Odds Ratio & $95 \% \mathrm{Cl}$ \\
\hline Opening-wedge & $\begin{array}{l}\text { Aspirin }(250) \\
\text { None }(3300)\end{array}$ & $\begin{array}{l}3(1.20) \\
15(0.45)\end{array}$ & 2.66 & $0.76-9.25$ \\
\hline Opening-wedge & $\begin{array}{l}\text { Anticoagulants }(373) \\
\text { None }(3300)\end{array}$ & $\begin{array}{c}2(0.54) \\
15(0.45)\end{array}$ & 1.18 & $0.27-5.18$ \\
\hline Opening-wedge & $\begin{array}{c}\text { Aspirin (250) } \\
\text { Anticoagulants (373) }\end{array}$ & $\begin{array}{l}3(1.20) \\
2(0.54)\end{array}$ & 2.25 & $0.37-13.58$ \\
\hline Closing-wedge & $\begin{array}{l}\text { Aspirin (62) } \\
\text { None (2373) }\end{array}$ & $\begin{array}{c}3(4.84) \\
48(2.02)\end{array}$ & 2.46 & $0.75-8.13$ \\
\hline Closing-wedge & $\begin{array}{l}\text { Anticoagulants }(737) \\
\quad \text { None }(2373)\end{array}$ & $\begin{array}{l}20(2.71) \\
48(2.02)\end{array}$ & 1.35 & $0.80-2.29$ \\
\hline Closing-wedge & $\begin{array}{c}\text { Aspirin (62) } \\
\text { Anticoagulants (737) }\end{array}$ & $\begin{array}{c}3(4.84) \\
20(2.71)\end{array}$ & 1.82 & $0.53-6.31$ \\
\hline
\end{tabular}

Table 6: Risk of DVT according to chemoprophylaxis used and type of osteotomy performed*.

Abbreviations: Cl-Confidence Interval; DVT-Deep Venous Thrombosis.

*None of the comparisons were statistically significant.

used anticoagulants postoperatively had a higher incidence of DVT. In addition, the risk of DVT was higher in closing-wedge osteotomy studies compared with opening-wedge studies regardless of the use of anticoagulants. This finding necessitated an analysis of the effect of anticoagulants and aspirin for each type of osteotomy separately. No significant difference was found in the risk of DVT in either 
opening-wedge or closing-wedge studies between knees that used anticoagulants or aspirin and those that did not. Because the incidence of venous thromboembolism events was very low regardless of the use of chemoprophylaxis, the necessity for anticoagulation after HTO in patients who do not have significant risk factors for venous thromboembolism events is questioned.

The indications for HTO have expanded to include patients who require correction of varus malalignment before meniscus transplantation, articular cartilage procedures, and knee ligament reconstruction $[10,11]$. The potential use of a thromboprophylaxis program may be justified in patients who undergo osteotomy due to the magnitude of the procedure; however, there are no recommendations from governing bodies or orthopaedic societies regarding a thromboprophylaxis program after HTO. A few authors have recommended that the thromboprophylaxis standards for TKA would be appropriate for HTO [2-4]. The American Academy of Orthopaedic Surgeons (AAOS) published a moderate recommendation for TKA in 2012 for the "use of pharmacologic agents and/or mechanical compressive devices" for patients who are not at elevated risk [12]. However, a specific prophylactic regimen after routine TKA could not be recommended based on current evidence $[12,13]$. The AAOS guidelines also stated that current evidence is unclear regarding whether factors other than a personal history of previous venous thromboembolism increase the risk of venous thromboembolism [14].

Erickson et al., recently reviewed the rates of symptomatic DVT and PE after HTO, distal femoral osteotomy, and tibial tubercle osteotomy in 141 patients who did not receive postoperative chemical prophylaxis [15]. Forty-seven of these patients underwent HTO. One patient developed a bilateral DVT after a medial opening-wedge osteotomy that progressed to $\mathrm{PE}$; this woman died 3 days after surgery. She was using oral contraceptives at the time of surgery and was subsequently found to have a maternal-side family history of DVT. Neither the patient nor her family physicians were aware of this history. For the entire series of 141 patients, the postoperative rates of DVT and PE were $1.42 \%$ and $0.71 \%$ respectively.

Significant risk factors for DVT include personal or family history of DVT, obesity, use of oral contraceptives and well-recognized hereditary disorders such as Factor V Leiden (FVL) mutation, prothrombin G20210A mutation, protein C deficiency, protein $S$ deficiency, and antithrombin III deficiency [16-21]. van der Meer et al. [22] reported that the risk of thromboembolism was increased seven-fold in individuals who were heterozygous for FVL and eight-fold for individuals who were homozygous for FVL. Other studies have observed that, while the presence of a genetic variant alone may not produce a venous thromboembolism, the addition of other risk factors such as oral contraceptive use $[23,24]$, hormone replacement therapy [25] and smoking [26] will magnify the risk. The use of oral contraceptives was reported to be associated with venous thromboembolism in data derived from 201 studies by Wu et al. [21]. The highest risk has been observed in women with Factor V Leiden (FVL) (OR - 15.62), followed by those with deficiencies in antithrombin $(\mathrm{OR}-12.60)$, protein $\mathrm{C}$ (OR - 6.33) and protein S (OR - 4.88). The discontinuation of oral contraceptives before surgery was not discussed in the osteotomy studies in this review. Pharmaceutical companies recommend that patients discontinue all estrogen products 4 to 6 weeks before any operation that has an increased risk of thromboembolism.

The use of aspirin for prophylaxis of venous thromboembolism events has gained recent interest after TKA [27-30] and from the
American College of Chest Physicians for patients undergoing major orthopaedic surgery [31]. A recent study of 4,651 primary total joint arthroplasty patients reported that low-dose aspirin $(81 \mathrm{mg}$ twice daily for 4 weeks) was not inferior to high-dose aspirin (325 mg twice daily for 4 weeks) for venous thromboembolism prophylaxis [29]. However, whether the routine use of aspirin after HTO in patients who do not have significant risk factors for venous thromboembolism events is justified remains unknown. We recommend that future HTO studies provide a description of prophylaxis programs (including dosage, duration and timing of medications) that include the use of compressive devices and early postoperative exercises. We have previously reported our program that includes intermittent pneumatic compression devices in both extremities for the first 24 hours, immediate knee range of motion exercises, early ambulation and partial weight-bearing, antiembolism stockings, and ankle pumps performed for $5 \mathrm{~min}$ utes every hour the patient is awake [32]. For surgeons who wish to use some form of chemical prophylaxis, we empirically recommend aspirin (325 mg/twice a day for 10 days). A Doppler ultrasound is immediately obtained with any suspicion of a DVT including abnormal calf tenderness, a positive Homan sign or increased lower extremity edema.

This literature review had several limitations. Of the 107 studies, $78 \%$ were Level-III or Level-IV investigations. There were no randomized high-level studies that compared different prophylaxis protocols. It was not possible to identify the number of patients in each study that were at increased risk of DVT. Even though some investigators did not describe a specific prophylaxis protocol in their study, they may have used medications, compressive devices or other measures to prevent venous thromboembolism events. There was a lack of agreement among the protocols published in regard to chemoprophylactic agents and their indications. While some protocols only used medications [9,33-38], others also incorporated compressive devices and/ or early knee motion and strengthening exercises [10,32,39-42]. The number of cases that used multiple prophylactic measures was too small to perform a valid comparison with those that used only chemoprophylaxis. In addition, a few studies only prescribed chemoprophylactic agents in patients with a history of DVT $[41,43]$. The limited number of knees in the subgroups shown in table 6 precludes definitive conclusions to be reached regarding our third and fourth questions. For instance, a post-hoc sample size analysis demonstrated that, in the opening-wedge aspirin versus anticoagulant comparison, a total of 17,497 knees would be required for statistical significance $(\mathrm{P}<0.05$, $80 \%$ probability) to be obtained. In the closing-wedge aspirin versus anticoagulant comparison, a total of 12,136 knees would be required for statistical significance to be reached.

\section{Conclusion}

Our study found that the incidence of venous thromboembolism events was very low after HTO, regardless of the use of chemoprophylaxis. Therefore, the necessity for anticoagulation after HTO in standard-risk patients is questioned considering the side effects that may occur with these agents.

\section{References}

1. Gardiner A, Gutiérrez Sevilla GR, Steiner ME, Richmond JC (2010) Osteotomies about the knee for tibiofemoral malalignment in the athletic patient. Am J Sports Med 38: 1038-1047.

2. Tunggal JA, Higgins GA, Waddell JP (2010) Complications of closing wedge high tibial osteotomy. Int Orthop 34: 255-261. 
Citation: Noyes FR, Barber-Westin SD, Levy MS (2017) Are Anticoagulants required after High Tibial Osteotomy to Prevent Venous Thromboembolism Events? A Systematic Review. J Orthop Res Physiother 3: 030.

3. Gomoll AH (2011) High tibial osteotomy for the treatment of unicompartmental knee osteoarthritis: a review of the literature, indications, and technique. Phys Sportsmed 39: 45-54.

4. Sherman C, Cabanela ME (2010) Closing wedge osteotomy of the tibia and the femur in the treatment of gonarthrosis. Int Orthop 34: 173-184.

5. Wright JM, Crockett HC, Slawski DP, Madsen MW, Windsor RE (2005) High tibial osteotomy. J Am Acad Orthop Surg 13: 279-289.

6. Liberati A, Altman DG, Tetzlaff J, Mulrow C, Gøtzsche PC, et al. (2009) The PRISMA statement for reporting systematic reviews and meta-analyses of studies that evaluate healthcare interventions: explanation and elaboration. BMJ 339: 2700.

7. Obremskey WT, Pappas N, Attallah-Wasif E, Tornetta P 3rd, Bhandari M (2005) Level of evidence in orthopaedic journals. J Bone Joint Surg Am 87: 2632-2638.

8. Wright JG, Swiontkowski MF, Heckman JD (2003) Introducing levels of evidence to the journal. J Bone Joint Surg Am 85: 1-3.

9. Aglietti P, Buzzi R, Vena LM, Baldini A, Mondaini A (2003) High tibial valgus osteotomy for medial gonarthrosis: a 10- to 21-year study. J Knee Surg 16 : 21-26.

10. Noyes FR, Barber-Westin SD, Hewett TE (2000) High tibial osteotomy and ligament reconstruction for varus angulated anterior cruciate ligament-deficient knees. Am J Sports Med 28: 282-296.

11. Noyes FR, Barber-Westin SD, Rankin M (2004) Meniscal transplantation in symptomatic patients less than fifty years old. J Bone Joint Surg Am 86: 1392-1404.

12. Mont M, Jacobs J, Lieberman J, Jay Parvizi, Paul Lachiewicz, et al.(2012) Preventing venous thromboembolic disease in patients undergoing elective total hip and knee arthroplasty. J Bone Joint Surg Am 94: 673-674.

13. Lieberman JR, Pensak MJ (2013) Prevention of venous thromboembolic disease after total hip and knee arthroplasty. J Bone Joint Surg Am 95: 18011811.

14. Jacobs JJ, Mont MA, Bozic KJ, Della Valle CJ, Goodman SB et al. (2012) American Academy of Orthopaedic Surgeons clinical practice guideline on: preventing venous thromboembolic disease in patients undergoing elective hip and knee arthroplasty. J Bone Joint Surg Am 94: 746-747.

15. Erickson BJ, Tilton A, Frank RM, Park W, Cole BJ (2017) Rates of Deep Vein Thrombosis Occurring After Osteotomy about the Knee. Am J Orthop (Belle Mead NJ) 46: 23-27.

16. Dziadosz M, Baxi LV (2016) Global prevalence of prothrombin gene mutation G20210A and implications in women's health: a systematic review. Blood Coagul Fibrinolysis 27: 481-489.

17. Grabowski G, Whiteside WK, Kanwisher M (2013) Venous thrombosis in athletes. J Am Acad Orthop Surg 21: 108-117.

18. de Haan HG, Bezemer ID, Doggen CJ, Le Cessie S, Reitsma PH, et al (2012) Multiple SNP testing improves risk prediction of first venous thrombosis. Blood 120: 656-663.

19. Middeldorp S (2011) Is thrombophilia testing useful? Hematology Am Soc Hematol Educ Program 2011: 150-155.

20. Ridker PM, Glynn RJ, Miletich JP, Goldhaber SZ, Stampfer MJ, et al. (1997) Age-specific incidence rates of venous thromboembolism among heterozygous carriers of factor V Leiden mutation. Ann Intern Med 126: 528-531.

21. Wu O, Robertson L, Twaddle S, Lowe GD, Clark P, et al. (2006) Screening for thrombophilia in high-risk situations: systematic review and cost-effectiveness analysis. The Thrombosis: Risk and Economic Assessment of Thrombophilia Screening (TREATS) study. Health Technol Assess 10: 1-110.

22. van der Meer FJ, Koster T, Vandenbroucke JP, Briët E, Rosendaal FR (1997) The Leiden Thrombophilia Study (LETS). Thromb Haemost 78: 631-635.

23. Emmerich J, Rosendaal FR, Cattaneo M, Margaglione M, De Stefano V, et al.(2001) Combined effect of factor V Leiden and prothrombin 20210A on the risk of venous thromboembolism--pooled analysis of 8 case-control studies including 2310 cases and 3204 controls. Study Group for Pooled-Analysis in Venous Thromboembolism. Thromb Haemost 86: 809-816.
24. Vandenbroucke JP, Rosing J, Bloemenkamp KW, Middeldorp S, Helmerhorst $\mathrm{FM}$, et al. (2001) Oral contraceptives and the risk of venous thrombosis. N Engl J Med 344: 1527-1535

25. Rosendaal FR, Vessey M, Rumley A, Daly E, Woodward M, et al. (2002) Hormonal replacement therapy, prothrombotic mutations and the risk of venous thrombosis. Br J Haematol 116: 851-854.

26. Juul K, Tybjaerg-Hansen A, Schnohr P, Nordestgaard BG (2004) Factor V Leiden and the risk for venous thromboembolism in the adult Danish population. Ann Intern Med 140: 330-337.

27. Stewart DW, Freshour JE (2013) Aspirin for the prophylaxis of venous thromboembolic events in orthopedic surgery patients: a comparison of the AAOS and ACCP guidelines with review of the evidence. Ann Pharmacother 47: 63-74.

28. Lewis CG, Inneh IA, Schutzer SF, Grady-Benson J (2014) Evaluation of the First-Generation AAOS Clinical Guidelines on the Prophylaxis of Venous Thromboembolic Events in Patients Undergoing Total Joint Arthroplasty: Experience with 3289 Patients from a Single Institution. J Bone Joint Surg Am 96: $1327-1332$.

29. Parvizi J, Huang R, Restrepo C, Chen AF, Austin, MS, et al. (2017) Low-Dose Aspirin Is Effective Chemoprophylaxis Against Clinically Important Venous Thromboembolism Following Total Joint Arthroplasty: A Preliminary Analysis. J Bone Joint Surg Am 99: 91-98.

30. Raphael IJ, Tischler EH, Huang R, Rothman RH, Hozack WJ, et al. (2014). Aspirin: an alternative for pulmonary embolism prophylaxis after arthroplasty? Clin Orthop Relat Res 472: 482-488.

31. Falck-Ytter Y, Francis CW, Johanson NA, Curley C, Dahl OE, et al. (2012) Prevention of VTE in Orthopedic Surgery Patients: Antithrombotic Therapy and Prevention of Thrombosis, 9th ed: American College of Chest Physicians Evidence-Based Clinical Practice Guidelines. Chest 141: 278-325.

32. Noyes FR, Mayfield W, Barber-Westin SD, Albright JC, Heckmann TP (2006) Opening wedge high tibial osteotomy: an operative technique and rehabilitation program to decrease complications and promote early union and function. Am J Sports Med 34: 1262-1273.

33. Demange MK, Sisto M, Rodeo S (2014) Future trends for unicompartmental arthritis of the knee: injectables \& stem cells. Clin Sports Med 33: 161-174.

34. Matar WY, Boscariol R, Dervin GF (2009) Open wedge high tibial osteotomy: a roentgenographic comparison of a horizontal and an oblique osteotomy on patellar height and sagittal tibial slope. Am J Sports Med 37: 735-742.

35. Valkering KP, van den Bekerom MP, Kappelhoff FM, Albers GH (2009) Complications after tomofix medial opening wedge high tibial osteotomy. J Knee Surg 22: $218-225$

36. van den Bekerom MP, Patt TW, Kleinhout MY, van der Vis HM, Albers GH (2008) Early complications after high tibial osteotomy: a comparison of two techniques. J Knee Surg 21: 68-74.

37. Arthur A, LaPrade RF, Agel J (2007) Proximal tibial opening wedge osteotomy as the initial treatment for chronic posterolateral corner deficiency in the varus knee: a prospective clinical study. Am J Sports Med 35: 1844-1850.

38. Hui C, Salmon LJ, Kok A, Williams HA, Hockers N, et al. (2011) Long-term survival of high tibial osteotomy for medial compartment osteoarthritis of the knee. Am J Sports Med 39: 64-70.

39. Song EK, Seon JK, Park SJ, Jeong MS (2010) The complications of high tibial osteotomy: closing- versus opening-wedge methods. J Bone Joint Surg $\mathrm{Br}$ 92: 1245-1252.

40. Akamatsu Y, Mitsugi N, Taki N, Takeuchi R, Saito T (2010) Simultaneous anterior cruciate ligament reconstruction and opening wedge high tibial osteotomy: Report of four cases. Knee 17: 114-118.

41. Laprade RF, Spiridonov SI, Nystrom LM, Jansson KS (2012) Prospective outcomes of young and middle-aged adults with medial compartment osteoarthritis treated with a proximal tibial opening wedge osteotomy. Arthroscopy 28: 354-364.

42. Miller BS, Downie B, McDonough EB, Wojtys EM (2009) Complications after medial opening wedge high tibial osteotomy. Arthroscopy 25: 639-646.

43. Hooper G, Leslie H, Burn J, Schouten R, Beci I (2005) Oblique upper tibial opening wedge osteotomy for genu varum. Oper Orthop Traumatol 17: 662673. 
Citation: Noyes FR, Barber-Westin SD, Levy MS (2017) Are Anticoagulants required after High Tibial Osteotomy to Prevent Venous Thromboembolism Events? A Systematic Review. J Orthop Res Physiother 3: 030.

Appendix 1: Studies included in systematic review

Studies that did not mention prophylaxis for deep venous thrombosis

Closing-wedge high tibial osteotomy [1-30]

Opening-wedge high tibial osteotomy [31-82]

Closing-wedge and opening-wedge high tibial osteotomy [83-87]

Studies that provided prophylaxis for deep venous thrombosis

Closing-wedge high tibial osteotomy [88-95]

Opening-wedge high tibial osteotomy [94-107]

\section{References}

1. Akizuki S, Shibakawa A, Takizawa T, Yamazaki I, Horiuchi H (2008) The long-term outcome of high tibial osteotomy: a ten- to 20-year follow-up. J Bone Joint Surg Br 90: 592-596.

2. Amendola A, Fowler PJ, Litchfield R, Kirkley S, Clatworthy M (2004) Opening wedge high tibial osteotomy using a novel technique: early results and complications. J Knee Surg 17: 164-169.

3. Aoki Y, Yasuda K, Mikami S, Ohmoto H, Majima T (2006) Inverted V-shaped high tibial osteotomy compared with closing-wedge high tibial osteotomy for osteoarthritis of the knee. Ten-year follow-up result. J Bone Joint Surg $\mathrm{Br}$ 88: $1336-1340$.

4. Backstein D, Meisami B, Gross AE (2003) Patella baja after the modified Coventry-Maquet high tibial osteotomy. J Knee Surg 16: 203-208.

5. Badhe NP, Forster IW (2002) High tibial osteotomy in knee instability: the rationale of treatment and early results. Knee Surg Sports Traumatol Arthrosc 10: 38-43.

6. Bauer T, Hardy P, Lemoine J, Finlayson DF, Tranier S, et al. (2005) Drop foot after high tibial osteotomy: a prospective study of aetiological factors. Knee Surg Sports Traumatol Arthrosc 13: 23-33.

7. Bauer S, Khan RJK, Ebert JR, Robertson WB, Breidahl W, et al. (2012) Knee joint preservation with combined neutralising high tibial osteotomy (HTO) and Matrix-induced Autologous Chondrocyte Implantation (MACl) in younger patients with medial knee osteoarthritis: a case series with prospective clinical and MRI follow-up over 5 years. Knee 19: 431-439.

8. Choi HR, Hasegawa Y, Kondo S, Shimizu T, Ida K, et al. (2001) High tibial osteotomy for varus gonarthrosis: a 10 - to 24 -year follow-up study. J Orthop Sci 6: 493-497.

9. Efe T, Ahmed G, Heyse TJ, Boudriot U, Timmesfeld N, et al. (2011) Closing-wedge high tibial osteotomy: survival and risk factor analysis at longterm follow up. BMC Musculoskelet Disord 12: 46.

10. Flamme CH, Ruhmann O, Schmolke S, Wichmann R (2003) Long-term outcome following high tibial osteotomy with tension bend principle. Archives of Orthopaedic and Trauma Surgery 123: 12-16.

11. Flecher X, Parratte S, Aubaniac JM, Argenson JN (2006) A 12-28-year followup study of closing wedge high tibial osteotomy. Clin Orthop Relat Res 452: 91-96.

12. Gstottner M, Pedross F, Liebensteiner M, Bach C (2008) Long-term outcome after high tibial osteotomy. Arch Orthop Trauma Surg 128: 111-115.

13. Huang TL, Tseng KF, Chen WM, Lin RM, Wu JJ, et al. (2005) Preoperative tibiofemoral angle predicts survival of proximal tibia osteotomy. Clin Orthop Relat Res 188-195.

14. Kawaguchi $H$, Jingushi S, Izumi T, Fukunaga M, Matsushita T, et al. (2007) Local application of recombinant human fibroblast growth factor-2 on bone repair: a dose-escalation prospective trial on patients with osteotomy. J Orthop Res 25: 480-487.

15. Koshino T, Yoshida T, Ara Y, Saito I, Saito T (2004) Fifteen to twenty-eight years' follow-up results of high tibial valgus osteotomy for osteoarthritic knee. Knee 11: 439-444.
16. Madan S, Ranjith RK, Fiddian NJ (2002) Intermediate follow-up of high tibial osteotomy: a comparison of two techniques. Bull Hosp Jt Dis 61: 11-16.

17. Majima T, Yasuda K, Katsuragi R, Kaneda K (2000) Progression of joint arthrosis 10 to 15 years after high tibial osteotomy. Clin Orthop Relat Res 177-184.

18. Marti RK, Verhagen RA, Kerkhoffs GM, Moojen TM (2001) Proximal tibial varus osteotomy. Indications, technique, and five to twenty-one-year results. J Bone Joint Surg Am 83: 164-170.

19. Omori G, Koga Y, Miyao M, Takemae T, Sato T, et al. (2008) High tibial osteotomy using two threaded pins and figure-of-eight wiring fixation for medial knee osteoarthritis: 14 to 24 years follow-up results. J Orthop Sci 13: 39-45.

20. Papachristou G, Plessas S, Sourlas J, Levidiotis C, Chronopoulos E, et al. (2006 ) Deterioration of long-term results following high tibial osteotomy in patients under 60 years of age. Int Orthop 30: 403-408.

21. Papp M, Csernatony Z, Kazai S, Karolyi Z, Rode L (2007) The patella and tibial condyle position after combined and after closing wedge high tibial osteotomy. Knee Surg Sports Traumatol Arthrosc 15: 769-780.

22. Papp M, Szabo L, Lazar I, Takacs I, Karolyi Z, et al. (2009) Combined high tibial osteotomy decreases biomechanical changes radiologically detectable in the sagittal plane compared with closing-wedge osteotomy. Arthroscopy 25: 355-364.

23. Pfahler M, Lutz C, Anetzberger H, Maier M, Hausdorf J, et al. (2003) Longterm results of high tibial osteotomy for medial osteoarthritis of the knee. Acta chir Belg 103: 603-606.

24. Sprenger TR, Doerzbacher JF (2003) Tibial osteotomy for the treatment of varus gonarthrosis. Survival and failure analysis to twenty-two years. J Bone Joint Surg Am 85: 469-474.

25. Stukenborg-Colsman C, Wirth CJ, Lazovic D, Wefer A (2001) High tibial osteotomy versus unicompartmental joint replacement in unicompartmental knee joint osteoarthritis: 7-10-year follow-up prospective randomised study. Knee 8: 187-194.

26. Weale AE, Lee AS, MacEachern AG (2001) High tibial osteotomy using a dynamic axial external fixator. Clin Orthop Relat Res 382: 154-167.

27. Williams RJ 3rd, Kelly BT, Wickiewicz TL, Altchek DW, Warren RF (2003) The short-term outcome of surgical treatment for painful varus arthritis in association with chronic ACL deficiency. J Knee Surg 16: 9-16.

28. Wu LD, Hahne HJ, Hassenpflug T (2004) A long-term follow-up study of high tibial osteotomy for medial compartment osteoarthrosis. Chin J Traumatol 7: 348-353.

29. Zaffagnini S, Bonanzinga T, Grassi A, Marcheggiani Muccioli GM, Musiani C, et al. (2013) Combined ACL reconstruction and closing-wedge HTO for varus angulated ACL-deficient knees. Knee Surg Sports Traumatol Arthrosc 21: 934-941.

30. Van Raaij T, Reijman M, Brouwer RW, Jakma TS, Verhaar JN (2008) Survival of closing-wedge high tibial osteotomy: good outcome in men with lowgrade osteoarthritis after 10-16 years. Acta Orthop 79: 230-234.

31. Abdel Megied WS, Mahran MA, Thakeb MF, Abouelela AA, Elbatrawy Y (2010) The new "dual osteotomy": combined open wedge and tibial tuberosity anteriorisation osteotomies. Int Orthop 34: 231-237.

32. Asik M, Sen C, Kilic B, Goksan SB, Ciftci F, et al. (2006) High tibial osteotomy with Puddu plate for the treatment of varus gonarthrosis. Knee Surg Sports Traumatol Arthrosc 14: 948-954.

33. Birmingham TB, Giffin JR, Chesworth BM, Bryant DM, Litchfield RB, Willits $\mathrm{K}$, et al. (2009) Medial opening wedge high tibial osteotomy: a prospective cohort study of gait, radiographic, and patient-reported outcomes. Arthritis Rheum 61: 648-57.

34. Bode G, Schmal H, Pestka JM, Ogon P, Südkamp NP, et al. (2013) A non-randomized controlled clinical trial on autologous chondrocyte implantation $(\mathrm{ACl})$ in cartilage defects of the medial femoral condyle with or without high tibial osteotomy in patients with varus deformity of less than $5^{\circ}$. Arch Orthop Trauma Surg 133: 43-49. 
Citation: Noyes FR, Barber-Westin SD, Levy MS (2017) Are Anticoagulants required after High Tibial Osteotomy to Prevent Venous Thromboembolism Events? A Systematic Review. J Orthop Res Physiother 3: 030.

35. Bonasia DE, Dettoni F, Sito G, Blonna D, Marmotti A, et al. (2014) Media Opening Wedge High Tibial Osteotomy for Medial Compartment Overload/ Arthritis in the Varus Knee: Prognostic Factors. Am J Sports Med 42: 690698.

36. Brinkman JM, Luites JW, Wymenga AB, van Heerwaarden RJ (2010) Early full weight bearing is safe in open-wedge high tibial osteotomy. Acta Orthop 81: 193-198.

37. Brosset T, Pasquier G, Migaud H, Gougeon F (2011) Opening wedge high tibial osteotomy performed without filling the defect but with locking plate fixation (TomoFix) and early weight-bearing: prospective evaluation of bone union, precision and maintenance of correction in 51 cases. Orthop Traumatol Surg Res 97: 705-711.

38. Chae DJ, Shetty GM, Wang KH, Montalban AS Jr, Kim JI, et al. (2011) Early complications of medial opening wedge high tibial osteotomy using autologous tricortical iliac bone graft and T-plate fixation. Knee 18: 278-284.

39. Collins B, Getgood A, Alomar AZ, Giffin JR, Willits K, et al. (2013) A case series of lateral opening wedge high tibial osteotomy for valgus malalignment. Knee Surg Sports Traumatol Arthrosc 21: 152-160.

40. Dallari D, Savarino L, Stagni C, Cenni E, Cenacchi A, et al. (2007) Enhanced tibial osteotomy healing with use of bone grafts supplemented with platelet gel or platelet gel and bone marrow stromal cells. J Bone Joint Surg Am 89: 2413-2420.

41. DeMeo PJ, Johnson EM, Chiang PP, Flamm AM, Miller MC (2010) Midterm follow-up of opening-wedge high tibial osteotomy. Am J Sports Med 38: 2077-2084.

42. Devgan A, Marya KM, Kundu ZS, Sangwan SS, Siwach RC (2003) Media opening wedge high tibial osteotomy for osteoarthritis of knee: long-term results in 50 knees. Med J Malaysia 58: 62-68.

43. El-Azab HM, Morgenstern M, Ahrens P, Schuster T, Imhoff AB, et al. (2011) Limb alignment after open-wedge high tibial osteotomy and its effect on the clinical outcome. Orthopedics 34: 622-628.

44. Floerkemeier S, Staubli AE, Schroeter S, Goldhahn S, Lobenhoffer P (2013) Outcome after high tibial open-wedge osteotomy: a retrospective evaluation of 533 patients. Knee Surg Sports Traumatol Arthrosc 21: 170-180.

45. Franceschi F, Longo UG, Ruzzini L, Marinozzi A, Maffulli N, et al. (2008) Simultaneous arthroscopic implantation of autologous chondrocytes and high tibial osteotomy for tibial chondral defects in the varus knee. Knee 15: 309-313.

46. Ganji R, Omidvar M, Izadfar A, Alavinia SM (2013) Opening wedge high tibial osteotomy using tibial wedge allograft: a case series study. Eur J Orthop Surg Traumatol 23: 111-114

47. Getgood A, Collins B, Slynarski K, Kurowska E, Parker D, et al. (2013) Short-term safety and efficacy of a novel high tibial osteotomy system: a case controlled study. Knee Surg Sports Traumatol Arthrosc 21: 260-269.

48. Gomoll AH, Kang RW, Chen AL, Cole BJ (2009) Triad of cartilage restoration for unicompartmental arthritis treatment in young patients: meniscus allograft transplantation, cartilage repair and osteotomy. J Knee Surg 22: $137-141$.

49. Gouin F, Yaouanc F, Waast D, Melchior B, Delecrin J, et al. (2010) Open wedge high tibial osteotomies: Calcium-phosphate ceramic spacer versus autologous bonegraft. Orthop Traumatol Surg Res 96: 637-645.

50. Harding AK, Toksvig-Larsen S, Tagil M, W-Dahl A (2010) A single dose zoledronic acid enhances pin fixation in high tibial osteotomy using the hemicallotasis technique. A double-blind placebo controlled randomized study in 46 patients. Bone 46: 649-654.

51. Haviv B, Bronak S, Thein R, Kidron A, Thein R (2012) Mid-term outcome of opening-wedge high tibial osteotomy for varus arthritic knees. Orthopedics 35: 192-196.
52. Hennig AC, Incavo SJ, Beynnon BD, Abate JA, Urse JS, et al. (2007) The safety and efficacy of a new adjustable plate used for proximal tibial opening wedge osteotomy in the treatment of unicompartmental knee osteoarthrosis. J Knee Surg 20: 6-14.

53. Iorio R, Pagnottelli M, Vadala A, Giannetti S, Di Sette P, et al. (2013) Openwedge high tibial osteotomy: comparison between manual and computer-assisted techniques. Knee Surg Sports Traumatol Arthrosc 21: 113-119.

54. Jung KA, Lee SC, Ahn NK, Hwang SH, Nam CH (2010) Radiographic healing with hemispherical allogeneic femoral head bone grafting for opening-wedge high tibial osteotomy. Arthroscopy 26: 1617-1624.

55. Keyhani S, Abbasian MR, Kazemi SM, Esmailiejah AA, Seyed Hosseinzadeh HR, et al. (2011) Modified retro-tubercle opening-wedge versus conventional high tibial osteotomy. Orthopedics 34: 90.

56. Kim SJ, Koh YG, Chun YM, Kim YC, Park YS, et al. (2009) Medial opening wedge high-tibial osteotomy using a kinematic navigation system versus a conventional method: a 1-year retrospective, comparative study. Knee Surg Sports Traumatol Arthrosc 17: 128-134.

57. Kolb W, Guhlmann H, Windisch C, Kolb K, Koller H, et al. (2009) Opening-wedge high tibial osteotomy with a locked low-profile plate. J Bone Joint Surg Am 92: 197-207.

58. Kuremsky MA, Schaller TM, Hall CC, Roehr BA, Masonis JL (2010) Comparison of autograft vs allograft in opening-wedge high tibial osteotomy. J Arthroplasty 25: 951-957.

59. Lee SC, Jung KA, Nam CH, Jung SH, Hwang SH (2010) The short-term follow-up results of open wedge high tibial osteotomy with using an Aescula open wedge plate and an allogenic bone graft: the minimum 1-year follow-up results. Clin Orthop Surg 2: 47-54.

60. Longino PD, Birmingham TB, Schultz WJ, Moyer RF, Giffin JR (2013) Combined tibial tubercle osteotomy with medial opening wedge high tibial osteotomy minimizes changes in patellar height: a prospective cohort study with historical controls. Am J Sports Med 41: 2849-2857.

61. Maffulli N, Loppini M, Longo UG, Denaro V, Oliva F (2013) Bovine xenograft locking Puddu plate versus tricalcium phosphate spacer non-locking Puddu plate in opening-wedge high tibial osteotomy: a prospective double-cohort study. Int Orthop 37: 819-826.

62. Naudie DD, Amendola A, Fowler PJ (2004) Opening wedge high tibial osteotomy for symptomatic hyperextension-varus thrust. Am J Sports Med 32: 60-70.

63. Nelissen EM, van Langelaan EJ, Nelissen RG (2010) Stability of medial opening wedge high tibial osteotomy: a failure analysis. Int Orthop 34: 217223.

64. Ozalay M, Sahin O, Akpinar S, Ozkoc G, Cinar M, et al. (2009) Remodeling potentials of biphasic calcium phosphate granules in open wedge high tibial osteotomy. Arch Orthop Trauma Surg 129: 747-752.

65. Ribeiro $\mathrm{CH}$, Severino NR, Cury Rde $\mathrm{P}$, de Oliveira VM, Avakian R, et al. (2009) A new fixation material for open-wedge tibial osteotomy for genu varum. Knee 16: 366-370.

66. Salzmann GM, Ahrens P, Naal FD, El-Azab H, Spang JT, et al. (2009) Sporting activity after high tibial osteotomy for the treatment of medial compartment knee osteoarthritis. Am J Sports Med 37: 312-328.

67. Santic V, Tudor A, Sestan B, Legovic D, Sirola L, et al. (2010) Bone allograft provides bone healing in the medial opening high tibial osteotomy. Int Orthop 34: $225-229$

68. Schroter S, Gonser CE, Konstantinidis L, Helwig P, Albrecht D (2011) High complication rate after biplanar open wedge high tibial osteotomy stabilized with a new spacer plate (Position HTO plate) without bone substitute. Arthroscopy 27 : 644-652.

69. Schroter S, Mueller J, van Heerwaarden R, Lobenhoffer P, Stockle U, et al. (2013) Return to work and clinical outcome after open wedge HTO. Knee Surg Sports Traumatol Arthrosc 21: 213-219. 
Citation: Noyes FR, Barber-Westin SD, Levy MS (2017) Are Anticoagulants required after High Tibial Osteotomy to Prevent Venous Thromboembolism Events? A Systematic Review. J Orthop Res Physiother 3: 030.

70. Shim JS, Lee SH, Jung HJ, Lee HI (2013) High tibial open wedge osteotomy below the tibial tubercle: clinical and radiographic results. Knee Surg Sports Traumatol Arthrosc 21: 57-63.

71. Spahn G (2004) Complications in high tibial (medial opening wedge) osteotomy. Arch Orthop Trauma Surg 124: 649-653.

72. Spahn G, Kirschbaum S, Kahl E (2006) Factors that influence high tibial osteotomy results in patients with medial gonarthritis: a score to predict the results. Osteoarthritis Cartilage 14: 190-195.

73. Staubli AE, De Simoni C, Babst R, Lobenhoffer P (2003) TomoFix: a new LCP-concept for open wedge osteotomy of the medial proximal tibia--early results in 92 cases. Injury 2: 55-62.

74. Takeuchi R, Ishikawa H, Aratake M, Bito H, Saito I, et al. (2009) Medial opening wedge high tibial osteotomy with early full weight bearing. Arthroscopy $25: 46-53$.

75. Takeuchi R, Umemoto Y, Aratake M, Bito H, Saito I, et al. (2010) A mid term comparison of open wedge high tibial osteotomy vs unicompartmental knee arthroplasty for medial compartment osteoarthritis of the knee. J Orthop Surg Res 5: 65.

76. Takeuchi R, Ishikawa H, Kumagai K, Yamaguchi Y, Chiba N, et al. (2012) Fractures around the lateral cortical hinge after a medial opening-wedge high tibial osteotomy: a new classification of lateral hinge fracture. Arthroscopy 28: 85-94.

77. van Hemert WL, Willems $\mathrm{K}$, Anderson PG, van Heerwaarden RJ, Wymenga AB (2004) Tricalcium phosphate granules or rigid wedge preforms in open wedge high tibial osteotomy: a radiological study with a new evaluation system. Knee 11: 451-456.

78. Wong KL, Lee KB, Tai BC, Law P, Lee EH, et al. (2013) Injectable cultured bone marrow-derived mesenchymal stem cells in varus knees with cartilage defects undergoing high tibial osteotomy: a prospective, randomized controlled clinical trial with 2 years' follow-up. Arthroscopy 29: 2020-2028.

79. Yacobucci GN, Cocking MR (2008) Union of medial opening-wedge high tibial osteotomy using a corticocancellous proximal tibial wedge allograft. Am J Sports Med 36: 713-719.

80. Zaki SH, Rae PJ (2009) High tibial valgus osteotomy using the Tomofix plate--medium-term results in young patients. Acta Orthop Belg 75: 360-367.

81. Zhang HN, Zhang J, Lv CY, Leng P, Wang YZ, et al. (2009) Modified biplanar open-wedge high tibial osteotomy with rigid locking plate to treat varus knee. J Zhejiang Univ Sci B 10: 689-695.

82. Zorzi AR, da Silva HG, Muszkat C, Marques LC, Cliquet A Jr, et al. (2011) Opening-wedge high tibial osteotomy with and without bone graft. Artif Organs 35: 301-307.

83. Brouwer RW, Bierma-Zeinstra SM, van Raaij TM, Verhaar JA (2006) Osteotomy for medial compartment arthritis of the knee using a closing wedge or an opening wedge controlled by a Puddu plate. A one-year randomised, controlled study. J Bone Joint Surg Br 88: 1454-1459.

84. Hankemeier S, Mommsen P, Krettek C, Jagodzinski M, Brand J, et al. (2010) Accuracy of high tibial osteotomy: comparison between open- and closedwedge technique. Knee Surg Sports Traumatol Arthrosc 18: 1328-1333.

85. Hoell S, Suttmoeller J, Stoll V, Fuchs S, Gosheger G (2005) The high tibial osteotomy, open versus closed wedge, a comparison of methods in 108 patients. Arch Orthop Trauma Surg 125: 638-643.

86. Luites JW, Brinkman JM, Wymenga AB, van Heerwaarden RJ (2009) Fixation stability of opening- versus closing-wedge high tibial osteotomy: a randomised clinical trial using radiostereometry. J Bone Joint Surg $\mathrm{Br}$ 91: $1459-1465$.

87. Savarino L, Cenni E, Tarabusi C, Dallari D, Stagni C, et al. (2006) Evaluation of bone healing enhancement by lyophilized bone grafts supplemented with platelet gel: a standardized methodology in patients with tibial osteotomy for genu varus. J Biomed Mater Res B Appl Biomater 76: 364-372.
88. Adili A, Bhandari M, Giffin R, Whately C, Kwok DC (2002) Valgus high tibial osteotomy. Comparison between an Ilizarov and a Coventry wedge technique for the treatment of medial compartment osteoarthritis of the knee. Knee Surg Sports Traumatol Arthrosc 10: 169-176.

89. Aglietti P, Buzzi R, Vena LM, Baldini A, Mondaini A (2003) High tibial valgus osteotomy for medial gonarthrosis: a 10- to 21-year study. J Knee Surg 16: 21-26.

90. Arthur A, LaPrade RF, Agel J (2007) Proximal tibial opening wedge osteotomy as the initial treatment for chronic posterolateral corner deficiency in the varus knee: a prospective clinical study. Am J Sports Med 35: 1844-1850.

91. Hui C, Salmon LJ, Kok A, Williams HA, Hockers N, et al. (2011) Long-term survival of high tibial osteotomy for medial compartment osteoarthritis of the knee. Am J Sports Med 39: 64-70.

92. Motycka T, Eggerth G, Landsiedl F (2000) The incidence of thrombosis in high tibial osteotomies with and without the use of a tourniquet. Arch Orthop Trauma Surg 120: 157-159.

93. Noyes FR, Barber-Westin SD, Hewett TE (2000) High tibial osteotomy and ligament reconstruction for varus angulated anterior cruciate ligament-deficient knees. Am J Sports Med 28: 282-296.

94. Song EK, Seon JK, Park SJ, Jeong MS (2010) The complications of high tibial osteotomy: closing- versus opening-wedge methods. J Bone Joint Surg $\mathrm{Br}$ 92: 1245-1252.

95. van den Bekerom MP, Patt TW, Kleinhout MY, van der Vis HM, Albers GH (2008) Early complications after high tibial osteotomy: a comparison of two techniques. J Knee Surg 21: 68-74.

96. Akamatsu Y, Mitsugi N, Taki N, Takeuchi R, Saito T (2010) Simultaneous anterior cruciate ligament reconstruction and opening wedge high tibial osteotomy: Report of four cases. Knee 17: 114-118.

97. Demange MK, Camanho GL, Pecora JR, Gobbi RG, Tirico LE, et al. (2011) Simultaneous anterior cruciate ligament reconstruction and computer-assisted open-wedge high tibial osteotomy: a report of eight cases. Knee 18: 387-391.

98. Esenkaya I, Elmali N (2006) Proximal tibia medial open-wedge osteotomy using plates with wedges: early results in 58 cases. Knee Surg Sports Traumatol Arthrosc 14: 955-961.

99. Hooper G, Leslie H, Burn J, Schouten R, Beci I (2005) Oblique upper Tibial opening wedge Osteotomy for Genu Varum. Operative Orthopadie und Traumatologie 17: 662-673.

100. LaPrade RF, Oro FB, Ziegler CG, Wijdicks CA, Walsh MP (2010) Patellar height and tibial slope after opening-wedge proximal tibial osteotomy: a prospective study. Am J Sports Med 38: 160-170.

101. Laprade RF, Spiridonov SI, Nystrom LM, Jansson KS (2012) Prospective outcomes of young and middle-aged adults with medial compartment osteoarthritis treated with a proximal tibial opening wedge osteotomy. Arthroscopy 28: 354-364

102. Marmotti A, Castoldi F, Rossi R, Marenco S, Risso A, et al. (2013) Bone marrow-derived cell mobilization by G-CSF to enhance osseointegration of bone substitute in high tibial osteotomy. Knee Surg Sports Traumatol Arthrosc 21: 237-248.

103. Matar WY, Boscariol R, Dervin GF (2009) Open wedge high tibial osteotomy: a roentgenographic comparison of a horizontal and an oblique osteotomy on patellar height and sagittal tibial slope. Am J Sports Med 37: 735-742.

104. Miller BS, Downie B, McDonough EB, Wojtys EM (2009) Complications after medial opening wedge high tibial osteotomy. Arthroscopy 25: 639-646.

105. Niemeyer P, Koestler W, Kaehny C, Kreuz PC, Brooks CJ, et al. (2008) Twoyear results of open-wedge high tibial osteotomy with fixation by medial plate fixator for medial compartment arthritis with varus malalignment of the knee. Arthroscopy 24: 796-804

106. Noyes FR, Mayfield W, Barber-Westin SD, Albright JC, Heckmann TP (2006) Opening wedge high tibial osteotomy: an operative technique and rehabilitation program to decrease complications and promote early union and function. Am J Sports Med 34: 1262-1273.

107. Valkering KP, van den Bekerom MP, Kappelhoff FM, Albers GH (2009) Complications after tomofix medial opening wedge high tibial osteotomy. $\mathrm{J}$ Knee Surg 22: 218-225. 